\title{
Homilia biskupa Grzegorza Rysia
}

BP DR HAB. GRZEGORZ RYŚ

Uniwersytet Papieski Jana Pawła II w Krakowie

To nie jest msza święta pogrzebowa, nie jesteśmy przy trumnie Księdza Arcybiskupa. Jesteśmy na Eucharystii, w której doświadczamy prawdy o świętych obcowaniu. Arcybiskup Józef ma się bardzo dobrze. Myślę, że znacznie lepiej niż większość z nas. I działa bardzo skutecznie, ponieważ bez niego to zgromadzenie dzisiejsze w żaden sposób by tak nie wyglądało. Bez niego dzisiaj tego wieczoru nie byłoby takiej koncelebry, bo każdy z nas ma swoje miejsca, w których odprawia msze i bez Arcybiskupa Józefa nie zeszlibyśmy się tutaj. To zgromadzenie też wyglądałoby inaczej, bo co każe przychodzić razem ludziom z dwóch uniwersytetów, z adwokatury i na przykład siostrom duchaczkom? Jest jeden człowiek, których wszystkich tych ludzi, wszystkich nas spaja i zaprasza. To Arcybiskup Józef. Nie sądzę, żeby chciał, by w czasie tej liturgii mówiono za dużo o nim, lecz myślę, że na koniec tego, co chcę powiedzieć, może dotkniemy choćby jednego $\mathrm{z}$ wymiarów jego życia, jego osobowości. 
Ale najpierw skoncentrujmy się bezpośrednio na słowie, które jak powiedziałem przed chwilą, prowadzi nas do ważnego znaku. Nie zawsze tak jest w liturgii, że słowo, które czytamy, domaga się od nas natychmiastowej odpowiedzi. A dzisiaj tak właśnie jest, że czytaliśmy słowo, na które mamy odpowiedzieć znakiem. Tym znakiem jest podłożenie głowy pod popiół, przyjęcie na siebie popiołu. Wezwanie, które w Ewangelii padło trzykrotnie, które nas przygotowuje na ten znak, najpierw brzmi tak: nie bądźcie aktorami w tym, co robicie. Niczego nie udawajcie. Nie bądźcie jak obłudnicy. Pierwsze znaczenie greckiego słowa, które jest użyte w tym tekście, to "aktorzy” - nie bądźcie aktorami. Człowiek może być aktorem we wszystkim, co robi. Może być aktorem nawet w najważniejszych swoich gestach. Dla Żyda biblijnego nie było ważniejszych rzeczy do zrobienia jak modlitwa, post i jałmużna. Trzy rzeczy, absolutnie najważniejsze postawy życiowe wierzącego Żyda. Jezus mówi: nie bądźcie aktorami w tym co najważniejsze. Nawet modląc się, nawet poszcząc, nawet dając jałmużnę, możesz tak naprawdę odgrywać jakąś sztukę. Można odegrać sztukę, posypując głowę popiołem. To bardzo ładny gest, taki teatralny. To bardzo sympatyczne, skądinąd. O co chodzi w tym wydarzeniu, które jest liturgią? Nie teatrem. My możemy zredukować tę liturgię do teatru, ale o co chodzi w tym wydarzeniu, które jest liturgią, a nie teatrem? Chodzi o bardzo ważną rzecz, chodzi o słowo „sprawiedliwość”. To jest słowo, które wytwarza napięcie między Ewangelią a drugim czytaniem. W drugim 
czytaniu słyszymy o sprawiedliwości Bożej, która jest szokująca. Sprawiedliwość Boża czyni grzechem tego, który nie znał grzechu. I wtedy my w Nim, w tym, który jest święty, a zostaje przez Ojca uczyniony grzechem, wtedy my w Nim stajemy się sprawiedliwi. Uczynieni sprawiedliwymi przez Boga. Sprawiedliwość, która przychodzi od Boga. Ale jest też sprawiedliwość, która jest sprawiedliwością ludzką i o tym mówi Ewangelia. Ewangelia daje kilka lekcji. Ale do tego, o czym teraz mówię, zainspirowała mnie lekcja, która jest pewnie lekcją większościową, a na tyle większościową, że Wulgata od czasów św. Hieronima po dzisiejszą wersję tłumaczy ten tekst, o którym teraz myślę, tak samo. Mianowicie pierwsze zdanie: „Strzeżcie się, żebyście uczynków pobożnych nie wykonywali przed ludźmi po to, aby Was widzieli”. Hieronim czytał „Strzeżcie się, abyście sprawiedliwości Waszej nie czynili przed ludźmi”. Napięcie między Ewangelią a tym drugim czytaniem to jest napięcie między sprawiedliwością Bożą a sprawiedliwością ludzką. Sprawiedliwością, którą dostajesz od Boga, która cię usprawiedliwia, a sprawiedliwością, która jest ludzka, tzn. taka, za pomocą której ty sam się usprawiedliwiasz. To jest napięcie między darem bycia sprawiedliwym przez łaskę Boga a pokusą, która w nas wszystkich siedzi. Pokusa to jest samousprawiedliwianie się. Ostatecznie my wszyscy wiemy, że jesteśmy grzesznikami. Grzech jest oczywistością w życiu każdego $\mathrm{z}$ nas. I wtedy, kiedy uświadamiamy sobie swój grzech, a jeszcze bardziej wtedy, kiedy ktoś inny nam go uświadamia, kiedy stawia nas w punkcie 
oskarżenia, kiedy mówi nam: jesteś winien, to najprostsza nasza reakcja jest taka: nie, nie, ja z tym nie mam nic wspólnego. A nawet jeśli wiem, że jestem winien, to teraz będę mnożył te wszystkie uczynki, będę oczywiście jałmużnę dawał na prawo i lewo, post wprowadzę od rana do nocy, trzy razy w tygodniu. No i żeby było pobożnie. Taka modlitewka, inna, piąta, piętnasta, trzydziesta. I wszystkie traktowane jako takie pobożne uczynki, którymi ostatecznie chcę przywalić ten mój grzech, który we mnie siedzi. Zakryć tę moją winę, żebym już jej nigdy więcej nie widział, i zdystansować się wobec niej, by zyskać sympatyczne poczucie bycia sprawiedliwym. Jestem w porządku i dlatego przed ludźmi to pokazuję, bo oni mi potwierdzą tak, tak, jesteś w porządku. Samousprawiedliwienie to taka chęć, żeby patrzeć w lustro z przekonaniem - nie jestem jak inni ludzie. Wtedy nawet ten popiół na głowę to jest po to, żeby jeszcze się podbudować. Jaki jestem pokorny, a tamci nie przyszli. I zobaczcie, św. Paweł stawia nas przed kompletnie inną perspektywą, kiedy mówi, że my jesteśmy sprawiedliwi, usprawiedliwieni przez Chrystusa w ten sposób, że On się staje naszym grzechem. Nie wiem, co myślicie o tym zdaniu. Ja myślę, że to jest jedno z najbardziej wstrząsających słów Pisma, że Bóg swojego Syna uczynił grzechem. Moim grzechem, moją pychą. Jezusa Chrystusa, który jest całą prawdą, Bóg czyni moim kłamstwem. On jest święty, Bóg Go czyni moim grzechem. On jest najpokorniejszy, Bóg Go czyni moją pychą. On jest najczystszy, Bóg Go czyni moją nieczystością. On jest ubogi, Bóg Go 
czyni moją chciwością. I to jest szokujące, bo kiedy ja się wyrzekam tych wszystkich swoich grzechów, tzn. udaję, że nie są moje - jakbym mógł, to bym się wobec każdego zdystansował, żeby ich tylko nie widzieć, żeby się tylko do nich nie przyznać - to On się do każdego z tych moich grzechów przyznaje do tego stopnia, że czyni je sobą. Bierze je na siebie. Staje się nimi. Po co? Po to, że kiedy umrze na krzyżu, to mój grzech umrze z Nim. I my jesteśmy dzisiaj $\mathrm{w}$ tej liturgii ustawieni przed taką alternatywą: albo będziemy stać ciągle przed Bogiem z takim poczuciem: przecież nie jestem taki do niczego, przecież potrafię zrobić to i to, nie wiedziałeś?; albo staniemy przed Nim $\mathrm{z}$ takim poczuciem, że z tego wszystkiego, z tej mojej jałmużny, z tej mojej modlitwy i z tego mojego postu tak naprawdę to ja mam w rękach popiół. I z tych wszystkich moich Hosan$n a$ ten popiół nie jest $\mathrm{z}$ niczego innego tylko z palm, które nieśliśmy triumfalnie w tamtym roku w Niedzielę Palmową i śpiewaliśmy Hosanna, Hosanna, Hosanna! Tyle z tego zostaje - popiół. Staniecie przed Bogiem w takim przekonaniu, że wszystko, co mamy w rękach, to jest popiół i dlatego też bierzemy go na głowę. A to jest to napięcie, które jest w liturgii dzisiaj. I najważniejsze jest to, że jeśli stanę przed Bogiem w taki sposób, to nie po to, żeby utracić jakąkolwiek nadzieję w stosunku do siebie, tylko żeby przeżyć to, że On mnie może z tego popiołu wskrzesić. I że to jest moment, kiedy się we mnie tak naprawdę odradza życie. Kiedy ja już nie muszę stać przed Bogiem i ciągle mówić, jestem jeszcze taki i taki. Nie muszę niczego na sobie 
budować. Mogę zbudować wszystko na Nim. W tym doświadczeniu, które nam zadaje papież Franciszek, które jest doświadczeniem miłosierdzia. I wtedy dopiero jest czas na wyzwolenie z człowieka każdego dobra, które wreszcie przestaje być szukaniem siebie i potwierdzaniem siebie. Nie muszę potwierdzać siebie, bo Bóg jest tym, który mnie potwierdza. Od początku do końca mnie potwierdza. Kocha mnie takiego, jakim jestem, nie muszę mu niczego udowadniać. I mogę wreszcie czynić dobro, które jest odpowiedzią. Zaczyna się jakaś niesamowita wymiana darów; jak będziesz czynił to w ukryciu, to Bóg ci odda. Jak Bóg oddaje? Zawsze z kopką, zawsze z nadmiarem. Bóg nigdy nie wylicza - dałeś piątkę, masz piątkę. Nie. Bóg zawsze daje $\mathrm{z}$ nadmiarem. Nie da się prześcignąć $\mathrm{w}$ dawaniu. Wtedy się zaczyna dopiero dawanie. Dawanie, które jest prawdziwe, które nie jest szukaniem siebie, nie jest potwierdzaniem siebie. Wtedy mają sens post, modlitwa i jałmużna, i każde dobro. Wszystko to, co jest miłosierdziem w stosunku do innych. Słuchaniem innych, otwarciem się na innych.

Wszyscy wiemy, że Arcybiskup Józef był człowiekiem niezwykłej otwartości. Miał zdolności do spotkania z człowiekiem, z każdym człowiekiem. Miał w sobie niesamowitą wrażliwość na człowieka. Przeczytajcie jego list na Wielki Post na rok 2002. To jest taki list, który do Ewangelii pasuje jak ulał. Arcybiskup mówi, zatroszczmy się o bezrobotnych, o ich rodziny. Zatroszczmy się o bezdomnych, o ubogich, o świetlice dla dzieci z najuboższych rodzin. Zatroszczmy się - to jest bardzo piękny fragment - o uzależnioną 
młodzież, bo może się okazać, że to, co potrafimy uczynić, czy na co się tylko zgodzimy, np. żeby w naszym sąsiedztwie powstał ośrodek dla uzależnionej młodzieży, to tak naprawdę sprawdzi nasze chrześcijaństwo. Taka otwartość, taka zdolność do rozmawiania z każdym, taka otwartość, która jest dostrzeżeniem miłosierdzia tego człowieka, który je zaprzepaścił, zmarnował. Taka otwartość nie bierze się z doświadczenia, że Bóg cię kocha takim, jaki jesteś. Jeśli my się dzisiaj zastanawiamy nad tym, czy możemy żyć choć trochę w zgodzie $\mathrm{z}$ tym znakiem, jakim dla nas jest Arcybiskup Józef, to musimy stwierdzić: naprawdę wiele zależy od tego, jak przeżyjemy ten znak posypania głowy popiołem. Bo jeśli przeżyjemy go w ten sposób, że Bóg nas po raz kolejny przyjmuje mimo tego, że my w rękach mamy tylko popiół, ale On nas przyjmuje, bo chce nas wskrzesić, bo nas kocha takimi, jakimi jesteśmy z takim popiołem w rękach, to my z kościoła wyjdziemy jako ludzie otwarci na każdą ludzką biedę i na każdą ludzką inność. Natomiast jeżeli będziemy stać przed Bogiem z takim poczuciem, z taką pokusą usprawiedliwienia siebie samego za wszelką cenę, to spotykając się z każdym innym i z Bogiem także, będziemy tylko ciągle patrzeć w siebie i będzie nam ciągle od początku do końca, nie daj Boże, chodziło o siebie samych. Amen. 